\title{
Do Green Business Initiatives Enhance Firm Performance? Evidence from an Emerging Market
}

\author{
Quyen Do Nguyen, Huyen Thi Thu Nguyen \\ Faculty of Banking and Finance, Foreign Trade University, Hanoi, Vietnam \\ Corresponding author: Quyen Do Nguyen, PhD, email: quyendn@ftu.edu.vn
}

Received 23 May 2020;

Accepted 30 May 2020;

Published 10June 2020;

\begin{abstract}
This paper examines the adoption of green business initiatives in Vietnamese firms' activities and their impacts on firm performance. We applied both qualitative and quantitative methods in this study. Our research results show that green initiatives have positive impacts on firm performance in terms of operating performance, financial performance, marketing performance and environmental performance. Green initiatives such as green supply chain management, reverse logistics, green logistics, green marketing, green advertising, eco-labeling, and green product innovation help firms grow and improve their revenues, profits, market shares and customers' satisfaction towards their products and services. In addition, green business initiatives contribute to firms' reduction in costs and negative impacts on the natural environment.
\end{abstract}

Key words: Green business initiatives, firm performance

\section{Introduction}

Under the current competitive and environmental pressure, finding the way to balance between economic benefits and environmental preservation has become urgent issues for firms. On the one hand, firms are required to comply with the environmental regulations of the country to develop sustainably. On the other hand, they should maintain the performance of the firm in the long run (Kushwaha and Sharma, 2016). Success in addressing environmental issues will create new opportunities for businesses to achieve sustainable development and create new competitive opportunities in the context of business environment (Kurdve et al., 2014; Tseng et al., 2014b; Shen et al., 2013; Tseng et al., 2015). Firms are acting beyond environmental norms by adopting green business initiatives such as green innovation, green supply management, green marketing etc. in their business activities (Ar Ilker, 2012). Chen $e t$ al. (2013) define green business initiatives as the hardware or the software innovation related to innovating products or processes, product design or environmental management of businesses including technological innovation to save energy, prevent pollution and recycle wastes.

Green business initiatives may vary from the innovation in the production of new products (goods and services) to the significant improvement of business processes, marketing activities, organizational management with a view to improving the environment and reducing negative environmental impacts (OECD, 2009). Green business initiatives can be applied in firm activities by using minimum natural resources throughout the business life cycle and per unit of production and limiting the emissions of hazardous substances into the environment to create cost-effective goods, services and management systems that meet the needs of consumers and bring quality of life to people (Reid and Miedzinski, 2008). Example of green business initiatives are green product innovation, green product design, procurement and supply chain management and reverse logistics, green marketing, green product advertising and eco labels (Kushwaha and Sharma, 2016).

Green business initiatives have been documented to enhance firm performance in recent studies (e.g. Simpson et al., 2007; Leonidou et al., 2012; Brecard, 2011; Kushwaha and Sharma, 2016; Agyabeng-Mensah et al., 2020). Firms with the welldeveloped environmental management systems are documented to have good environmental performance (Simpson et al., 2007). In automotive industry, the performance of the firm is significantly positively affected by environmental initiatives since customers have preferences towards energy-saving products (Kushwaha and Sharma, 2016). In a survey of KPMG in 2014, it is found that $92 \%$ of the buyer consider fuel-efficient vehicles while $73 \%$ of the customers care for eco-friendly products and $47 \%$ prefer a car with alternative fuel technologies (KPMG, 2014). Brecard (2011) found that when automobile firms apply green business initiatives (i.e. green supply chain management), they can reduce life cycle cost, improve asset efficiency, reduce waste, innovate service and recycling which lead to better firm performance.

Although many studies support that green business initiatives enhance firm performance, the benefits of green initiatives remain unconvincing to many managers because they concern that the costs related to implementing these initiatives outweigh their benefits (Leonidou et al., 2012). However, if we compare between the investment costs of green business initiatives with the extra fees that firms must pay to deal with their carbon emission or environmental pollution, these extra fees could be a lot more. Thus, the objective of this research is to examine how Vietnamese firms apply green business initiatives in their activities and investigate the relationship between green business initiatives and firm performance. 
Both qualitative and quantitative research methodology were applied in this research. To empirically test the theoretical framework, this research constructs a questionnaire to examine the adoption of green business initiatives and run the OLS models to investigate the impact of green business initiatives on firm performance. Green business initiatives are reflected by green supply chain management (GSCM), reverse logistics, green logistics, green marketing, green advertising, eco-labeling, and green product innovation. Firm performance is reflected by financial performance, operational, environmental, and financial performance. A 5-point Likert scale was used to measure the items in the questionnaire. OLS regression models are employed to examine the relationships between each green initiative and overall green business initiatives and firm performance. The sample of this study includes 312 listed firms on Vietnam stock exchange. The data were collected from November 2019 to January 2020. SPSS 20 was used to analyse the data and run the empirical models.

Overall, our research results show that green business initiatives have statistically significant positive impacts on Vietnamese firm performance. Among the initiatives, green marketing, green advertising, and green product innovation have consistently and significantly positive relationships with financial performance, operational, environmental, and financial performance. These results confirm the crucial role of green business initiatives in enhancing firm performance and suggest that firms should not hesitate in applying these initiatives in the business activities to develop in a sustainable way.

This study is divided into 5 sections. Section 2 provides a theoretical framework and a literature on the impact of green business initiatives on firm performance. Section 3 summarises research methodology. Section 4 analyses the research results and section 5 concludes.

\section{Theoretical framework and hypothesis development}

\subsection{Green business initiatives}

Green business initiatives or green business innovation are defined as "hardware or software innovation related to green products or processes, including innovation in technologies that are involved in energy-saving, pollution-prevention, waste recycling, green product designs corporate environmental management" (Chen et al., 2013). Green business initiatives can also be understood as the applications of new or modified products, processes, techniques and practices to avoid or reduce environmental harms (Beise-Zee and Rennings, 2005). Firm's objective in adopting green initiatives is to reduce pressure to comply with environmental norms and build up better image by keeping business in a sustainable manner (Smith, 2010)
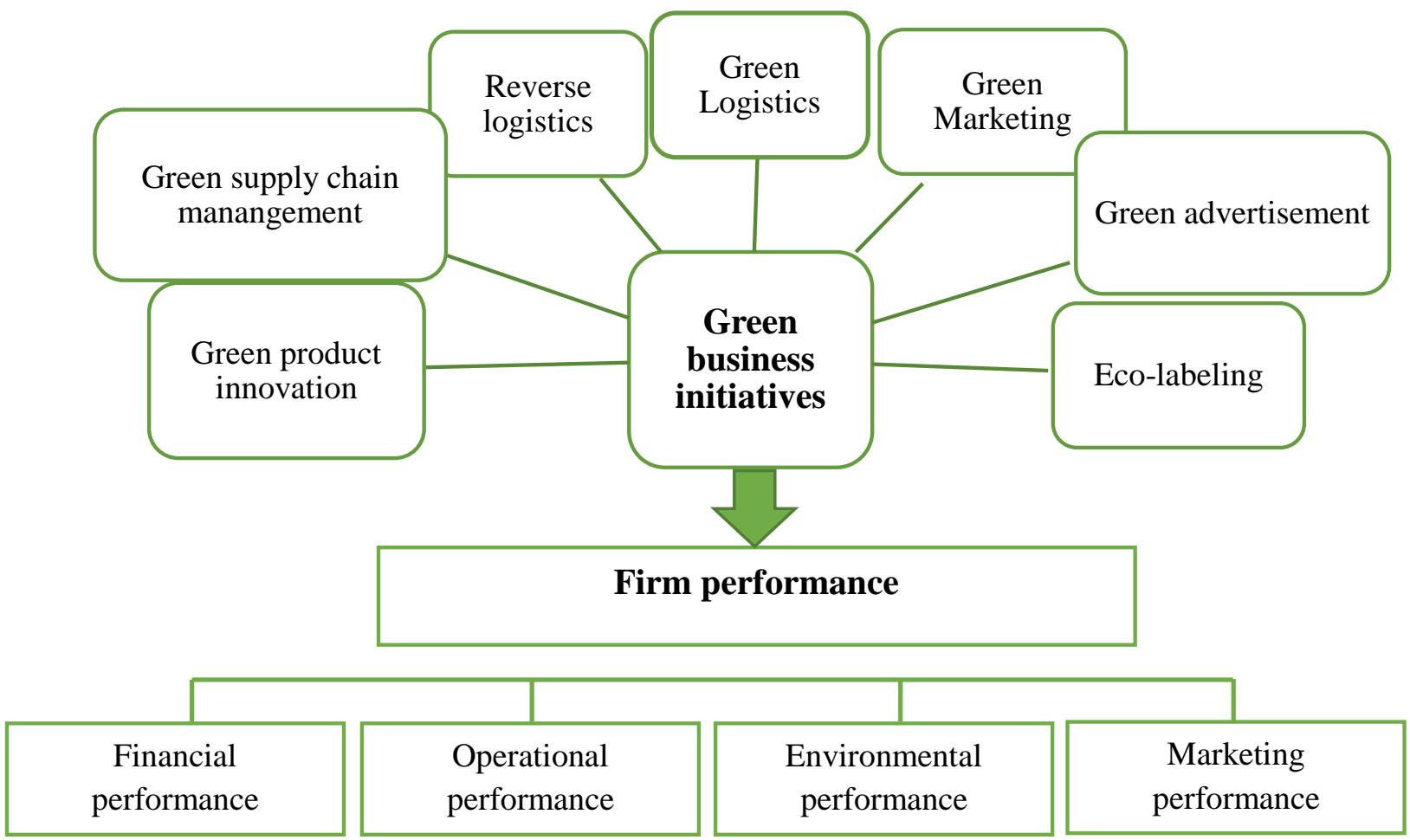

\section{Figure 1: The theoretical framework}

In this paper, green business initiatives are defined as initiatives that innovate products, business activities and management systems with the goal of reducing the negative environmental impact to achieve ecological goals. These initiatives may involve green product improvement activities, green product design, environment-friendly materials procurement, green supply chain management and reverse logistics, green logistics, green marketing, eco-labeling and green product advertising (Smith, 2010; Kushwaha and Sharma, 2016). Firm performance can be classified into financial, operational, environmental, and marketing performance (Kushwaha and Sharma, 2016). Therefore, this study focuses on green business initiatives and examines the relationship between green business initiatives and firm financial, operational, environmental, and marketing performance. The theoretical framework of this research can be seen in Figure 1.

\subsection{Green business initiatives and firm performance}

2.2.1. Green supply chain management and firm performance 
Green supply chain management (GSCM) is defined as activities related to green procurement and business investment restructuring (Chan et al., 2012a). Put differently, GSCM is the corporate governance from the procurement of raw materials to the delivery of product to reduce the negative impact on the environment. GSCM might include the process of selecting environment-friendly materials, green product design and green packaging, etc. GSCM can be divided into two parts: internal and external environmental management (Rao, 2002). Internal environmental management focuses on the support and commitment of firms to conduct GSCM in compliance with environmental management systems and regulations being implemented within the organization (Zhu and Sarkis, 2004). External environmental management involves greening corporate suppliers so that they can engage together with firms in achieving environmental goals (Bowen et al., 2001; Rao, 2002). This also includes green procurement, cooperation with customers to meet the environmental requirements, investment restructuring, eco-friendly product designs applying or green products innovating (Rao and Holt, 2005; Chen et al., 2013).

The positive relationship between GSCM and firm performance has been found in many studies. Azevedo et al. (2011) point out that the application of GSCM brings significant benefits to firms not only in their operational, financial, and environmental performance but also in their cost savings and ecosystem preservation. The application of GSCM plays an important role in traditional supply chain management. GSCM helps reduce the waste to the environment and reduce cost through reverse logistics and increase efficiency of firms to achieve better performance and sustainable development (Chan et al., 2012b). Nowadays, businesses must integrate their supply chains with environmental governance due to increasing pressure from customers who have environmental concerns. In addition, businesses can create more business opportunities than their competitors and expand their market share if they can successfully solve environmental problems (Hansmann and Claudia, 2001).

In automobile industry, Brecard (2011) found that GSCM is the prominent factor to help manufacturers reduce life cycle cost, improve asset efficiency, reduce waste, innovate service and recycling. He highlights that green business initiatives such as GSCM are parts of sustainability programs and help firms enhance performance. However, there are many barriers affecting the firms' GSCM approach such as market competition, instability, cost, etc. Removing these barriers will help firms successfully implement GSCM in the Indian automobile industry (Luthra et al., 2011). Car manufacturing firms in some developing countries, such as China or Malaysia, have implemented GSCM and have started to learn from international partners (Lin et al., 2013). The industrialization, especially in the automobile sector, has created an environmental burden yet created great opportunities for firms to apply GSCM to achieve economic efficiency and sustainable development (Lin et $a l ., 2013)$. The green supply chain is an important strategy for China's automotive industry to achieve sustainably environmental, economic, and social development (Zhu et al., 2004).

The impact of GSCM is also found in the efficient use of resource and environmental protection of firms. Most logistics and transportation firms that implement green supply chain models have improvements in energy and waste reduction as well as packaging reduction in distribution. Firms must comply with all environmental and legal regulations. In this case, GSCM acts as an intermediary and has the significant positive impact on firm performance (Chan et al., 2012a). Besides, GSCM, sustainable growth and firm performance are related (Hervani et al., 2005). The application of the GSCM initiative is also found to have a positive impact on the share price of firms (Bose and Pal, 2012). A lot of studies have supported a positive relationship between GSCM and firm performance, thus, our hypothesis is as follows:

\section{H1: There is a positive relationship between GSCM and firm performance.}

\subsubsection{Reverse logistics and firm performance}

Reverse logistics is defined as the last continuation of the product life cycle including recycling, reuse, etc. and maintaining product sustainability (Kushwaha and Sharma, 2016). Reverse logistics is one of the important factors in GSCM. With reverse logistics, firms can implement an eco-friendly business strategy and promote consumer awareness for sustainable development (Hazen et al., 2012). German car suppliers always focus on quality, cost, time and environmental-friendly processes. Green supply chain management thrives in the German market due to its environmental policy. If enterprises supply components and accessories that do not apply green technology, they may lose market share or face the risk of business closure because environmental concerns are the top priority in most countries (Caniels, 2013). Car parts manufacturers have identified the application of GSCM as their strategy (Mathiyazhagan and Govindan, 2013). Many studies show that government regulations and reverse logistics are the key drivers for achieving cooperation between the product designers and suppliers, thereby, reduce the negative impact on the environment and implement GSCM successfully (Diabat and Govindan, 2011). Therefore, our hypothesis is as follows:

\section{H2: There is a positive relationship between reverse logistics and} firm performance.

\subsubsection{Green logistics and firm performance}

Rodrigue et.al (2012) define green logistics as activities and strategies in supply chain management to minimize the environmental impacts and energy consumption of commodity distribution, focusing on material handling, waste management, goods packaging and shipping from warehouse to customers. Green logistics include measuring the environmental impact of different distribution strategies, reducing energy use in logistics, reducing waste and managing operations (Sbihi and Eglese, 2009). From a sustainable development perspective, green logistics is defined as the sustainable production and distribution of goods and services, taking into account environmental and social factors.

Green logistics are viewed as the solution for the firms with the increasing concern of the environment as they incorporate the reuse of materials and production components which are also known as reserve logistics and waste management (Dias and Braga, 2016). Green logistics management practice contributes to the reduction of waste and energy consumption and the increase in customers' satisfaction, which leads to the increase in firms' financial, operational, and environmental performance. Besides, green logistics management also helps improve health and welfare of society through reducing the air pollution emanating from greenhouse gasses from transportation (Baah et al., 2019). Research findings points out that green logistics are needed for enhancing environmental sustainability (Centobelli et al., 2018; Khan et al., 2019). Especially, green packaging, reuse, remanufacturing, proper disposal of used products, the use of ecofriendly fuels for transportation and the use of green sources of energy ensure firm environmental performance (Demirel et al., 2016). We then hypothesize that there is a positive relationship between green logistics and firm performance. 
H3: The relationship between green logistics and firm performance is positive.

\subsubsection{Green marketing and firm performance}

Green marketing is defined as an enterprise's marketing activities associated with its ethical and social responsibility requirements (Dheeraj and Vishal, 2012). Ko et al. (2013) highlight that green marketing is related to business image building activities to enhance the capacity of businesses in all aspects. For instance: green images of firms are built with different keywords such as eco-friendly, recyclable, green products, or environmentally friendly product packaging.

Green marketing can be considered as ethical compliance and social responsibility requirements in marketing (Dheeraj and Vishal, 2012). Green marketing is closely related to building the company's image, helping to improve the company's ability in all aspects (Ko et al., 2013). Fisk (2010) points out that green marketing and sustainable technology are factors that promote financial efficiency, marketing efficiency and sustainable development of firms. In addition, the eco-friendly marketing strategy can change the behavior of consumers in a positive way, however, the information must be transmitted repeatedly to achieve the consistent change. It is also suggested that the positive impact of behavior change strategies contribute to the increase in the behavior of green consumers (Siriwardena et al., 2012). Many studies also confirm the positive impact of ecological information on promoting green consumption behavior. For instance: Green et al. (2012) mentioned the positive impacts of harmonizing green marketing strategies on the supply chain particularly and the marketing activities of firms in general, thereby improving firm financial performance.

Green product images include products with environmentally friendly features, recyclability, and green package. Eco-friendly products positively influence the reputation of the company and its image (Smith, 2012). In addition, other research results point out that there is a relationship between proactive environmental strategies and firm performance and suggest that managers should consider green marketing as a strategy because it not only contributes to reducing costs but also optimizes business results and contributes to create comparative advantages (Fraj et al., 2011). In fact, consumers have increasing preference towards green products (Saxena and Khandelwal, 2008). General Motors has invested US \$ 2.5 billion in green business (Gleim, 2013). Firms adopt green strategies such as green innovation, organizational greening, and green alliances (Cronin et al., 2011). Moreover, green marketing also brings sustainability to businesses (Peattie and Crane, 2005). Companies are working to improve their products in a greener manner for a number of reasons, including the desire to become more socially responsible businesses (Polonsky et al., 1998). Thus, our hypothesis is as follows:

\section{H4: Green marketing is positively related to firm performance.}

\subsubsection{Green advertisement and firm performance}

Green advertising is green communication strategies that focus on promoting the product's eco-friendly characteristics in order to attract customers to buy green or eco-friendly products (Smith, 2012). Thanks to green advertising, green products increasingly attract customers. Word of mouth communication is one of the important media of green advertising to promote green products and promote consumer awareness (Chen et al., 2013).

If green products need to ensure all factors such as quality, price, packaging, recycling and distribution system to minimize environmental pollution, green advertising will act as a tool to highlight these features and increase the competitiveness of products of firms in the market (Kushwaha and Sharma, 2016). Green advertising helps consumers get access to green products more closely and friendly. Therefore, green advertising not only contributes to improve the image of the business, increase marketing efficiency but also guides consumers to change their green purchasing habits.

It can be said that green advertising or green messages also help attract consumers to believe in the media (Grimmer and Wooley, 2014). Customers are often attracted to green products in green advertising. Green advertising makes consumers to buy green products and feel environmentally friendly (Smith, 2012). The research results document the positive impact of ecological information and its role in increasing the behavior of green consumers (Siriwardena et al., 2012). Available ecological information of firm products can educate consumers about the benefits of choosing a greener lifestyle (Borin and Cerf, 2011). The industries in India have positive views of adopting green lifestyles (Saxena and Khandelwal, 2012). Even goodwill can have a positive impact on corporate profits through output prices (Kristrom and Lundgreen, 2003). In addition, environmental performance creates a positive image of firms. Therefore, implementing a green advertising can bring benefits to firms (Camino, 2007). Therefore, our hypothesis is as follows:

\section{H5: Green advertising is positively related to firm performance.}

\subsubsection{Eco-labeling and firm performance}

Eco-labeling is defined as a logo or symbol on a firm's product, showing its environmental concerns. It can be said that eco-labels are one of the important means of marketing strategies in promoting green products for firms. The eco-label itself, also known as the environmental label, is a useful tool for firms to pass on green messages to customers that they commit themselves to develop sustainably and solve environment-related problems. Firms need to promote strategies related to green branding, ecolabeling, and green packaging to encourage green consumption trends of consumers (Juwaheer et al., 2012).

If firms' products are granted eco-labels, these products are recognized as environmentally friendly products. When products are eco-labeled, firms have created images of law compliance, especially the environment law; thus, creating the most competitive advantage, especially in the markets with high social responsibility and environmental requirements to the community. Eco-labeling stands out as one of the prominent means of marketing communications for green information of products although moving towards a sustainable production and consumption system is still far away (Rex and Baumann, 2007). Ecological or ecolabels are useful tools to show the cooperation and selfcommitment of firms in the industries (Panda and Goswami, 2009).

In addition, eco-labels are important tools to support decision making regarding products that pay attention to environmental factors (Thogersen et al., 2010). Therefore, companies develop advertising strategies, green brands, eco-labels and green packaging to encourage green consumption patterns (Juwaheer et al., 2012). Images and messages from eco-labels bring a positive impact on consumers and their purchasing decisions, thereby, positively affecting the firm performance (Tang et al., 2004). As a result, our hypothesis is as follows:

H6: Eco-labeling and firm performance is positively related. 


\subsubsection{Green product innovation and firm performance}

Green product innovation is the product improvement and innovation activities of firms to make their products greener and more eco-friendly, save fuel and reduce the negative environmental impacts. Green product innovation has become the key to the success of businesses today. Green product innovation not only makes a difference for businesses but also for the whole industry, thereby improving firm's environmental performance. business environment. Once the market demand focuses on sustainable green products, firms will inevitably succeed (Lin et al., 2013).

Green product innovation has become the key to the firm success today, and green product innovation not only makes a difference to businesses but also to industries, thereby, improving the environmental performance. Innovation and leadership during the transition period are also one of the important factors in firm operations (Samad, 2012). Lin et al. (2013) point out that market demand is positively correlated with firm performance and green product innovation. Once the market demand is towards green products in a sustainable way, businesses are bound to succeed (Lin et al., 2013). Companies that are actively involved in green product innovation have better business results than those that are less actively involved or do not focus on green product innovation (Camison and Lopez, 2012). Many motorcycle manufacturing companies in Vietnam have taken actions to integrate product innovation with firm operation to improve firm performance (Lin et al., 2013). In addition to focusing on products and firm performance, businesses need to pay attention to their environmental performance to achieve sustainable growth. When examining the impact of green product improvement on firm performance and competitiveness, Ar Ilker (2012) concludes that green product improvement has a positive impact on firms' business results and competitiveness.

Green product innovation can be achieved by implementing a minimum resource use development process (RCPD - Resource Constrained Product Development) (Kushwaha and Sharma, 2016). RCPD is the process of developing new products that use minimum resources and at the lowest possible cost so that the product price is also affordable. Developing products that use minimal resources can help the product enter the market at a lower cost and provides unexpected benefits such as the use of economic resources, thereby, protecting scarcity of natural resources to contribute to the sustainable development (Sharma and Iyer, 2012). In short, green product innovation is an inevitable trend of businesses for sustainable development. The benefits of green product innovation for businesses are not only in firm performance but also in environmental performance.

It can be said that most of the above-mentioned studies support the positive impacts of green business initiatives on firm performance. Therefore, our hypotheses are as follows:

H7: Green product innovation and firm performance is positively related.

H8: Overall, green business initiatives are positively related to firm performance.

\section{Research methodology}

\subsection{Sample and data collection}

This study applied both qualitative and quantitative research methods. Questionnaire survey was designed to collect primary data. The questionnaire was constructed based on literature on green business initiatives and firm performance. We applied 5point Likert scale to measure the frequency of green business initiatives application and the impacts of green business initiatives on financial, operation, environmental and marketing performance. The questionnaire was first sent out to a few firms for pilot test on its consistency, clarity, and length. After receiving feedbacks, we made some changes to the questionnaire in terms of clarity, scale, and instruments. Our final version of questionnaire was sent out to more than 500 listed firms on Vietnam stock exchange via mail and email. The process took place for 2 months (December $2019-$ January 2020). Our final sample consists of 312 valid responses which excludes responses with missing values. This sample includes firms of different industries. We use SPSS 20 software to analyse the data and to run the model. Cronbach Alpha and Exploratory Factor Analysis (EFA) were conducted to measure the reliability of the instruments and evaluate the convergence and discriminant values of the variables, respectively. We also used OLS regression to examine the relationship between green business initiatives and firm performance.

\subsection{Variables construction}

Table 1 summarises how variables were constructed in the questionnaire. Green business initiatives variables were built on 5point Likert scales to examine the frequency of firms in applying these initiatives (scaling from 1-Never to 5-Always). Green supply chain management were measured by 3 observed variables such as GI1A, GI1B and GI1C, indicating the process of GSCM which includes green procurement, product design, using renewable energy and cleaner technology and green product distribution. Reverse logistics, denoted as GI2, describe firms' product recycling and reuse to maintain the sustainability of the products. Green logistics was also included as the separate observed variable of green initiative (a.k.a. GI3) although it has some overlapped content with GSCM and reverse logistics.

Green marketing (denoted as GI4) was constructed to examine whether firms build a green image of business, promote ecofriendly products and services, and develop green marketing policies such as price, distribution, and communication. Green adverting was measured through GI5 to test whether firms advertise or promote green products and services of firms. Ecolabeling was proxied as GI6 to examine if firms apply eco-labels onto their products. Green product innovation (denoted as GI7) measures how firms innovate and improve products/services to reduce negative impacts on the environment. These initiatives may vary from the firms' compliance with the environmental regulations to other initiatives such as product innovation towards natural resources preservation and environmental friendliness, waste reduction, etc. to mitigate negative effects on the ecology.

Firm performance (FP) is proxied by financial, operational, environmental, and marketing performance. 5-point Likert scale was used to examine the impact of green business initiatives on firm performance (scaling from 1-Totally disagree to 5-Totally agree). Financial performance (FP) was measured by 3 indicators such as profitability, market value and firm growth. Operational performance (OP) was reflected through revenue and costs. Environmental performance (EP) measures how much firms can reduce polluted wastes in air, water, and land, and use fewer natural resources when apply green business initiatives. Finally, marketing performance (MP) was measured through customers' satisfaction and willingness to buy green products and services, and market share improvement. 


\section{Table 1: Variables construction}

\begin{tabular}{|c|c|c|c|}
\hline Factors & Codes & Factor indicators & References \\
\hline \multicolumn{4}{|l|}{ Green business initiatives } \\
\hline \multirow[t]{3}{*}{$\begin{array}{l}\text { Green supply chain } \\
\text { management }\end{array}$} & GI1A & $\begin{array}{l}\text { Select and purchase environmentally friendly/ } \\
\text { recycling raw materials to produce, design and pack } \\
\text { eco-friendly goods. }\end{array}$ & \multirow{3}{*}{$\begin{array}{l}\text { Bowen et al., 2001; Rao, 2002; Zhu } \\
\text { and Sarkis, 2004; Rao and Holt, } \\
\text { 2005; Azevedo et al., 2011; Chan et } \\
\text { al., 2012a; Chan et al., 2012b; Chen } \\
\text { et al., 2013; Kushwaha and Sharma, } \\
\text { 2016. }\end{array}$} \\
\hline & GI1B & $\begin{array}{l}\text { Use renewable energy, cleaner technology } \\
\text { equipment instead of natural resources in production } \\
\text { and recycling to reduce emissions and waste. }\end{array}$ & \\
\hline & GI1C & $\begin{array}{l}\text { Distribute product (including storage, order } \\
\text { processing, pick-up, packaging, delivery) to limit } \\
\text { negative environmental impacts. }\end{array}$ & \\
\hline Reverse logistics & GI2 & $\begin{array}{l}\text { Recycle and reuse used goods and materials to } \\
\text { maintain product sustainability. }\end{array}$ & $\begin{array}{l}\text { Diabat and Govindan, 2011; Hazen } \\
\text { et al., 2012; Kushwaha and Sharma, } \\
2016 .\end{array}$ \\
\hline Green logistics & GI3 & $\begin{array}{l}\text { Transport and deliver goods and services to } \\
\text { customers to minimize negative impacts on the } \\
\text { ecological environment. }\end{array}$ & $\begin{array}{l}\text { Rodrigue et.al 2012; Dias and } \\
\text { Braga, 2016; Centobelli et al., 2018; } \\
\text { Khan } \text { et al., 2019. }\end{array}$ \\
\hline Green marketing & GI4 & $\begin{array}{l}\text { Building a green image of business, promote eco- } \\
\text { friendly products and services and develop green } \\
\text { marketing policies (price, distribution, } \\
\text { communication) }\end{array}$ & $\begin{array}{l}\text { Fisk 2010; Dheeraj and Vishal, } \\
\text { 2012; Siriwardena et al., 2012; Ko et } \\
\text { al., 2013. }\end{array}$ \\
\hline Green advertising & GI5 & $\begin{array}{l}\text { Advertise/ promote products and services of firms } \\
\text { that are environmentally friendly. }\end{array}$ & $\begin{array}{l}\text { Camino, 2007; Smith, 2012; } \\
\text { Kushwaha and Sharma, 2016. }\end{array}$ \\
\hline Eco-labeling & GI6 & Eco-labeling on the products of the firms & $\begin{array}{l}\text { Panda and Goswami, 2009; } \\
\text { Juwaheer } \text { et al., } 2012 .\end{array}$ \\
\hline Green product innovation & GI7 & $\begin{array}{l}\text { Innovate and improve products/ services to } \\
\text { significantly reduce negative impacts on the } \\
\text { environment }\end{array}$ & $\begin{array}{l}\text { Samad, 2012; Ar Ilker 201; Lin et } \\
\text { al., 2013. }\end{array}$ \\
\hline \multicolumn{4}{|l|}{ Firm performance } \\
\hline \multirow[t]{3}{*}{ Financial performance } & FI1 & Profitability improvement & \multirow{11}{*}{$\begin{array}{l}\text { Zhu and Sarkis, 2004; Ar Ilker 2012; } \\
\text { Kushwaha and Sharma, 2016; } \\
\text { Agyabeng-Mensah, 2020. }\end{array}$} \\
\hline & FI2 & Increase in market value & \\
\hline & FI3 & Firm growth increases & \\
\hline \multirow[t]{3}{*}{ Operational performance } & OP1 & Revenue increases & \\
\hline & OP2 & Costs decreases & \\
\hline & OP3 & Costs increases but at a lower level than revenue & \\
\hline \multirow[t]{2}{*}{ Environmental performance } & EP1 & Reduction of polluted wastes in air, water and land. & \\
\hline & EP2 & $\begin{array}{l}\text { Less use in natural resources such as: energy, } \\
\text { electricity, gas, diesel... }\end{array}$ & \\
\hline \multirow[t]{3}{*}{ Marketing performance } & MP1 & $\begin{array}{l}\text { Customers' satisfaction on green products and } \\
\text { services }\end{array}$ & \\
\hline & MP2 & $\begin{array}{l}\text { Customers' willingness to continue buying green } \\
\text { products and services }\end{array}$ & \\
\hline & MP3 & Market share improvement & \\
\hline
\end{tabular}

\subsection{Model specification}

In order to empirically test the relationship between green business initiatives and firm performance, OLS regression models were employed. We tested the relationships between each green business initiative (such as GSCM, reverse logistics, green logistics, green marketing, green advertising, eco-labeling, and green product innovation) with firm performance (including financial, operating, environmental and marketing performance). Our models are as follows:

Model 1:

$F P_{i}=\alpha+\alpha_{1} G I_{i 1}+\alpha_{2} G I_{i 2}+\alpha_{3} G I_{i 3}+\alpha_{4} G I_{i 4}+\alpha_{5} G I_{i 5}+\alpha_{6} G I_{i 6}+\alpha_{7} G I_{i 7}+\varepsilon$

Where: FP is financial performance; GI1 is GSCM; GI2 is reverse logistics; GI3 is green logistics; GI4 is green marketing; GI5 is green advertising; GI6 is eco-labeling; GI7 is green product innovation; $i$ stands for firm; and $\varepsilon$ is the standard error.

Model 2: 
$O P_{i}=\beta+\beta_{1} G I_{i 1}+\beta_{2} G I_{i 2}+\beta_{3} G I_{i 3}+\beta_{4} G I_{i 4}+\beta_{5} G I_{i 5}+\beta_{6} G I_{i 6}+\beta_{7} G I_{i 7}+\zeta$

Where: OP is operational performance; GI1 is GSCM; GI2 is reverse logistics; GI3 is green logistics; GI4 is green marketing; GI5 is green advertising; GI6 is eco-labeling; GI7 is green product innovation; $i$ stands for firm; and $\zeta$ is the standard error.

Model 3:

$E P_{i}=\delta+\delta_{1} G I_{i 1}+\delta_{2} G I_{i 2}+\delta_{3} G I_{i 3}+\delta_{4} G I_{i 4}+\delta_{5} G I_{i 5}+\delta_{6} G I_{i 6}+\delta_{7} G I_{i 7}+\theta$

Where: EP is environmental performance; GI1 is GSCM; GI2 is reverse logistics; GI3 is green logistics; GI4 is green marketing; GI5 is green advertising; GI6 is eco-labeling; GI7 is green product innovation; $i$ stands for firm; and $\theta$ is the standard error.

\section{Model 4:}

$M P_{i}=\partial+\partial_{1} G I_{i 1}+\partial_{2} G I_{i 2}+\partial_{3} G I_{i 3}+\partial_{4} G I_{i 4}+\partial_{5} G I_{i 5}+\partial_{6} G I_{i 6}+\partial_{7} G I_{i 7}+\gamma$

Where: MP is marketing performance; GI1 is GSCM; GI2 is reverse logistics; GI3 is green logistics; GI4 is green marketing; GI5 is green advertising; GI6 is eco-labeling; GI7 is green product innovation; $i$ stands for firm; and $\gamma$ is the standard error.

Model 5:

$$
F P_{i}=\lambda+\lambda_{1} G I_{i 1}+\xi
$$

Where: FP is firm performance and is reflected through 4 categories such as financial, operating, environmental and marketing performance; GI is the synthesis of green business initiatives including GSCM, reverse logistics, green logistics; green marketing, green advertising, eco-labeling and green product innovation; $i$ stands for firm; and $\xi$ is the standard error.

\section{Result discussion}

\subsection{Descriptive statistics}

Table 2: Descriptive statistics on green business initiatives and firm performance

\begin{tabular}{|c|c|c|c|c|c|c|}
\hline Variables & Obs. & Mean & S.D. & P25 & P50 & P75 \\
\hline GI1A & 312 & 2.452 & 1.353 & 1 & 2 & 4 \\
\hline GI1B & 312 & 2.151 & 1.405 & 1 & 1 & 3 \\
\hline GI1C & 312 & 1.651 & 0.839 & 1 & 1 & 2 \\
\hline GI2 & 312 & 1.808 & 1.160 & 1 & 1 & 2 \\
\hline GI3 & 312 & 1.561 & 0.873 & 1 & 1 & 2 \\
\hline GI4 & 312 & 2.731 & 1.404 & 1 & 3 & 4 \\
\hline GI5 & 312 & 2.593 & 1.429 & 1 & 2 & 4 \\
\hline GI6 & 312 & 1.221 & 0.721 & 1 & 1 & 1 \\
\hline GI7 & 312 & 3.038 & 1.344 & 2 & 3 & 4 \\
\hline FP1 & 312 & 2.561 & 1.331 & 1 & 3 & 4 \\
\hline FP2 & 312 & 2.458 & 1.257 & 1 & 2 & 3 \\
\hline FP3 & 312 & 2.260 & 1.221 & 1 & 2 & 3 \\
\hline OP1 & 312 & 2.692 & 1.446 & 1 & 3 & 4 \\
\hline $\mathrm{OP} 2$ & 312 & 2.119 & 1.256 & 1 & 2 & 3 \\
\hline OP3 & 312 & 2.279 & 1.352 & 1 & 2 & 3 \\
\hline EP1 & 312 & 3.026 & 1.170 & 2 & 3 & 4 \\
\hline EP2 & 312 & 3.006 & 1.335 & 2 & 3 & 4 \\
\hline MP1 & 312 & 2.859 & 1.219 & 2 & 3 & 4 \\
\hline MP2 & 312 & 2.907 & 1.103 & 2 & 3 & 4 \\
\hline MP3 & 312 & 2.676 & 1.070 & 2 & 3 & 3 \\
\hline
\end{tabular}

Note: FP is financial performance; OP is operational performance; EP is environmental performance; MP is marketing performance; GI1 A,B,C measure GSCM; GI2 reverse logistics; GI3 is green logistics; GI4 is green marketing; GI5 is green advertising; GI6 is eco-labeling; GI7 is green product innovation.

Table 2 reports descriptive statistics of how Vietnamese listed firms apply green business initiatives and how they evaluate their impacts on firm performance. GI1A, B, C measures GSCM by three components such as green materials procurement, product packing and design, renewable energy application and green distribution. Among these components, green materials procurement, product packing and design seem to outweigh others in GSCM. Under $75^{\text {th }}$ percentile of firms regularly buys environment-friendly or recycled materials to produce their products and focuses on green product design and packing in green supply chain management. Renewable energy and cleaner technology equipment are applied by fewer firms with the mean of 
2.15. Green product distribution is less applied by firms. Reverse logistics and green logistics are used at the modest level with the mean of 1.808 and 1.561 , respectively. The results show that green marketing and green advertising tend to be applied quite regularly by Vietnamese firms. Under $75^{\text {th }}$ percentile of firms applies these initiatives at the scale of 4 out of 5-point Likert scale. Eco-labeling (GI6) seems to be least used by firms with the mean value of 1.221. Nevertheless, green product innovation (GI7) is used quite frequently to the negative impacts on the ecology.

Figure 1 shows the frequency of green business initiatives application vary among different industries in Vietnam. In GSCM, the green material procurement, green design, and packaging (GI1A) is mostly used by Healthcare equipment \& services,
Technology hardware \& equipment, Household \& personal product, and Agriculture. Meanwhile, on average, Healthcare equipment \& services industry ranks the first in frequently applying renewable energy, cleaner technology equipment (GI1B) instead of natural resources in production and recycling to reduce emissions and waste. Green product distribution (GI1C) in GSCM is mostly used in Agriculture/Agriculture chemicals industry and Energy. The frequency of applying reverse logistics (GI2) is highest in Automobile \& industry, followed by Healthcare equipment \& services, Food beverage \& tobacco, Energy and Commercial \& Personal industry. These industries have recycled and reused used goods and materials to maintain product sustainability.
GI1A

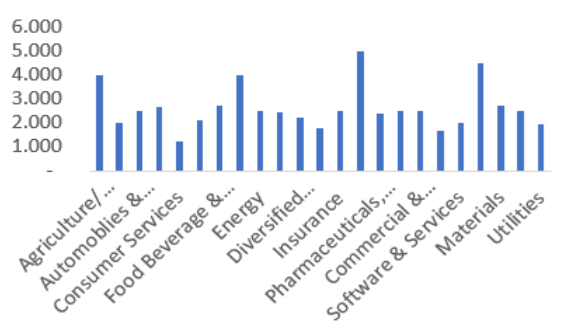

$\mathrm{GI} 2$

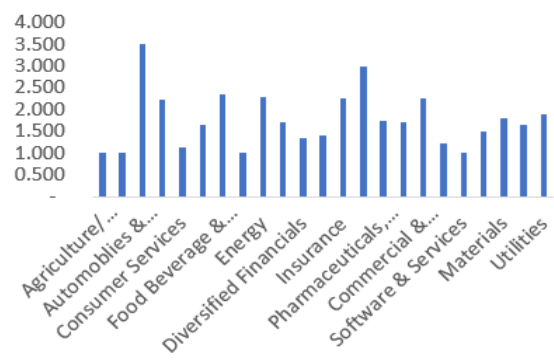

GI5

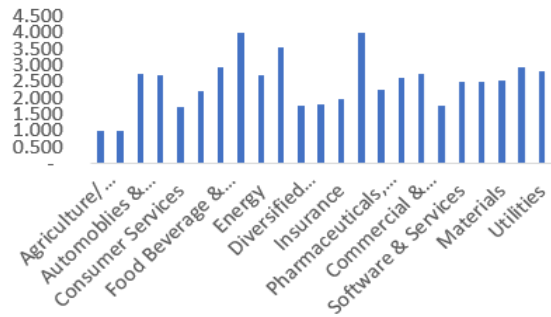

GI1B

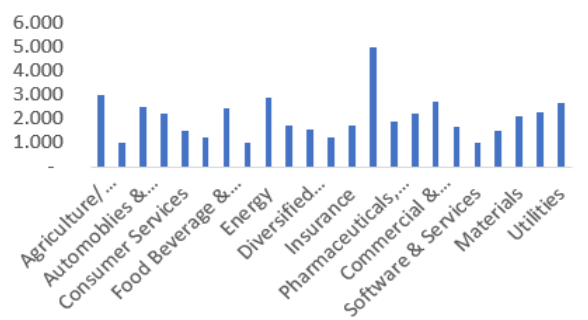

$\mathrm{GI3}$

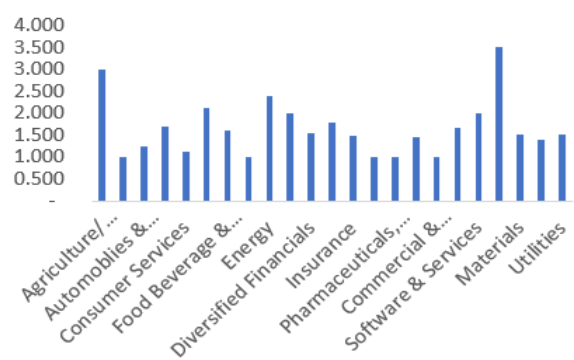

GI6

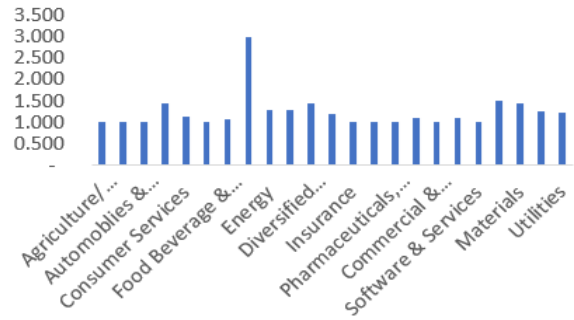

GI1C

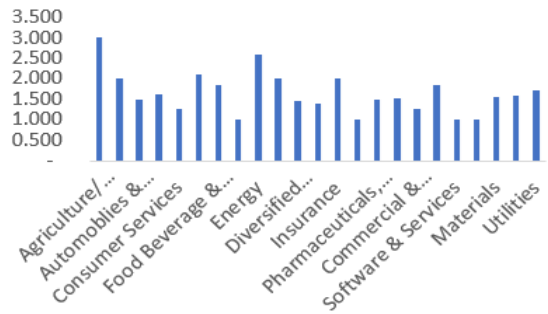

GI4

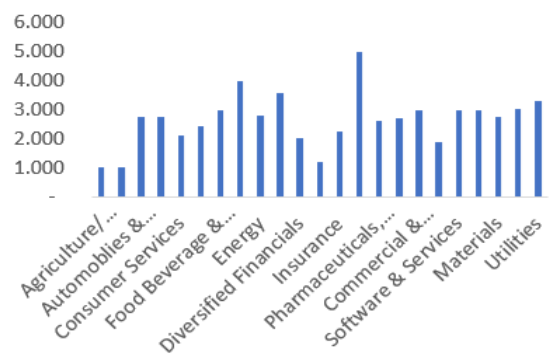

GI7

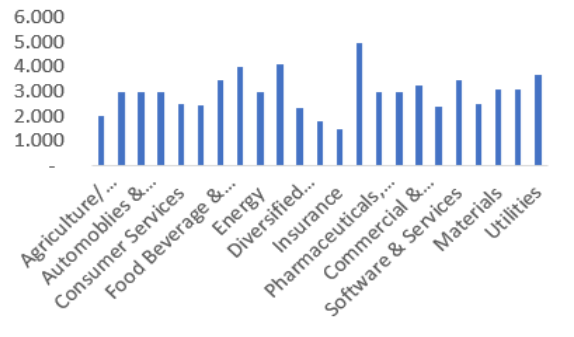

Figure 2: Green business initiatives application by industry

Green logistics (GI3) is found to be mostly used by Technology hardware \& equipment industry, followed by Agriculture and Energy. Regarding green marketing (GI4), Healthcare equipment \& services and Household \& personal product industry are the two industries that apply this initiative most often. Among the green initiatives, green advertising (GI5) seems to be applied by many industries. Firms working in Healthcare equipment \& services and Household \& personal product and Banking industry usually use green advertising to promote products and services of firms that are environmentally friendly. Besides, other industries that also employ green advertising are Food beverage \& tobacco,
Automobile \& industry, Consumer durable \& apparel, Energy, Capital goods, Commercial \& Personal industry, Real estates, Utilities, Software \& services, and Technology hardware \& equipment. Eco-labeling (GI6) is mostly applied by firms in Household \& personal product industry only. Finally, green product innovation (GI7) is usually employed by many industries among green business initiatives. In comparison with other industries, Healthcare equipment \& services, Household \& personal product, Banking, Food beverage \& tobacco and Utilities industry innovate their products and services more frequently to significantly reduce negative impacts on the environment.

\subsection{Reliability tests and EFA analysis}


Cronbach Alpha was used to test the reliability of variables in reflecting the factors. If Cronbach's Alpha is greater than 0.6, it means that the variables, used to measure the factor are reliable. GI's Cronbach's Alpha is 0.860 which indicates that the observed variables (from GI1 to GI7 including GSCM, reverse logistics, green logistics, green marketing, green advertising, eco-labeling and green product innovation) are reliable to describe the main characteristics of green business initiatives (GI). When GSCM was tested whether the variables GI1A, GI1B and GI1C reliably reflect the characteristics of GSCM, it was found that GI1C Cronbach's Alpha was higher than the overall GSCM's Cronbach's Alpha. As the result, GI1C was omitted due to its unreliability. In terms of firm performance, financial performance (FI), operational performance (OP), environmental performance (EP) have Cronbach's alpha values of $0.891,0.616,0.833$ and 0.89 , respectively. These values all satisfy the requirements, thus, the data used in this study are reliable (see Table 3 for details).

Corrected Item-Total correlation values of all factors are greater than 0.3 and Cronbach's Alpha if item deleted are lower than factors' overall Cronbach's Alpha. Therefore, the observed variables are valid and reliable to reflect the factors. Kaiser-MeyerOlkin (KMO) measure of sampling adequacy reports satisfactory coefficients of $0.868,0.727,0.519,0.5$ and 0.738 for GI, FP, OP, EP and MP, respectively. Besides, Bartlett's test of sphericity findings also documents significant results for both green initiatives and firm performance factors.

Exploratory Factor Analysis (EFA) was also used to evaluate the convergence and differentiations values of the scales. We conducted EFA for both dependent variables (FP, OP, EP and MP) and independent variables (GI). Empirical studies recommend that with the sample size of more than 300 observations, the factor loading should be more than 0.3 . The EFA results indicate that most of the scales meet the requirements although GI3 seems to be a bit weaker in loading factor. It can be understood that the firms in the sample of the study vary from industries to industries and not many of them apply green logistics in their activities. Therefore, this green initiative is not as strong as other variables in explaining GI. However, since it is almost the same as the threshold of 0.3 , we remain GI3 as one of our observed variables.

Table 3: Reliability and validity construction

\begin{tabular}{|c|c|c|c|c|}
\hline Factor & Cronbach's Alpha & Factor loading & $\begin{array}{ll}\text { Corrected } & \text { Item-Total } \\
\text { Correlation } & \end{array}$ & $\begin{array}{llll}\begin{array}{l}\text { Cronbach's Alpha } \\
\text { Deleted }\end{array} & & & \text { Item } \\
\end{array}$ \\
\hline \multicolumn{5}{|l|}{$\overline{\text { GI }}$} \\
\hline GI1 & \multirow[t]{7}{*}{0.860} & 0.859 & 0.777 & 0.818 \\
\hline GI2 & & 0.655 & 0.541 & 0.852 \\
\hline GI3 & & 0.298 & 0.226 & 0.883 \\
\hline GI4 & & 0.900 & 0.824 & 0.808 \\
\hline GI5 & & 0.891 & 0.810 & 0.810 \\
\hline GI6 & & 0.498 & 0.397 & 0.859 \\
\hline GI7 & & 0.870 & 0.784 & 0.815 \\
\hline \multicolumn{5}{|l|}{ FP } \\
\hline FP1 & \multirow[t]{3}{*}{0.891} & 0.870 & 0.725 & 0.890 \\
\hline FP2 & & 0.927 & 0.822 & 0.813 \\
\hline FP3 & & 0.924 & 0.817 & 0.820 \\
\hline \multicolumn{5}{|l|}{ OP } \\
\hline OP1 & \multirow[t]{3}{*}{0.616} & 0.907 & 0.601 & 0.224 \\
\hline OP2 & & 0.378 & 0.375 & 0.610 \\
\hline OP3 & & 0.890 & 0.555 & 0.319 \\
\hline \multicolumn{5}{|l|}{ EP } \\
\hline EP1 & \multirow[t]{2}{*}{0.833} & 0.928 & 0.721 & \\
\hline$\overline{\mathrm{EP} 2}$ & & 0.928 & 0.721 & \\
\hline \multicolumn{5}{|l|}{ MP } \\
\hline MP1 & \multirow[t]{3}{*}{0.891} & 0.916 & 0.805 & 0.832 \\
\hline MP2 & & 0.922 & 0.819 & 0.817 \\
\hline MP3 & & 0.882 & 0.744 & 0.881 \\
\hline
\end{tabular}

Note: GI is the first factor that represents green business initiatives and is reflected by observed variables from GI1-7; FP is the second factor that represents financial performance and is reflected by instrumental variables from FP1-3; OP is the third factor that represents operational performance and is reflected by variables from OP1-3; EP is the fourth factor that represents environmental performance and is reflected by observed variables from EP1-2; MP is the fifth factor that represents marketing performance and is reflected by variables from MP1-3; GI1 measure GSCM; GI2 is reverse logistics; GI3 is green logistics; GI4 is green marketing; GI5 is green advertising; GI6 is eco-labeling; GI7 is green product innovation.

Table 4 reports the multicollinearity in a set of variables that reflects green business initiatives. VIF (1) shows the inner VIF of observed variables from GI1 to GI7. Kock (2015) suggested that the VIF values for each observed variable should be $<3.3$ to conclude that there is no collinearity among variables. The research results show that there exists collinearity between GI4 and GI5 as
VIF values of these two variables exceed 3.3. To deal with this multicollinearity, we separated GI4 and GI5 in our models running to fully capture the relationship of both green marketing and green advertising with firm performance. When GI4 and GI5 were separated, the problem of multicollinearity was solved (VIF values were reported in VIF (2) and VIF (3) in Table 4).

Table 4: Variance inflation factor 


\begin{tabular}{|l|l|l|l|}
\hline Variables & VIF (1) & VIF (2) & VIF (3) \\
\hline GI1 & 2.660 & 2.615 & 2.599 \\
\hline GI2 & 1.506 & 1.502 & 1.506 \\
\hline GI3 & 1.077 & 1.077 & 1.077 \\
\hline GI4 & 4.617 & & 3.030 \\
\hline GI5 & 4.246 & 2.786 & \\
\hline GI6 & 1.199 & 1.195 & 1.186 \\
\hline GI7 & 3.133 & 2.803 & 2.999 \\
\hline
\end{tabular}

Note: GI1 measure GSCM; GI2 is reverse logistics; GI3 is green logistics; GI4 is green marketing; GI5 is green advertising; GI6 is ecolabeling; GI7 is green product innovation.

\subsection{Regression results discussion}

Table 5 reports the regression models results that document the relationship between each green initiative with financial, operational, environmental, and marketing performance. Due to the multicollinearity between GI4 and GI5, we incorporated these variables into 2 different groups of models (Models $1.1-4.1$ and models $2.1-4.2)$ to examine the impacts of each initiative on financial, operational, environmental, and marketing performance. Our findings show that GSCM (GI1) has a positive relationship with marketing performance at $5 \%$ level of significance. This result is in line with studies by Azevedo et al., (2011), Chan et al., (2012a) and Chan et al., (2012b). The positive relationship between GSCM and marketing performance indicates the firms that select and purchase environmentally friendly or recycling raw materials to produce, design and pack eco-friendly goods and use renewable energy, cleaner technology equipment instead of natural resources will contribute to increasing customers' satisfaction on green products and improving market share. In addition, the customers will be willing to continue buying green products of the companies with GSCM application. The relationships between GSCM and financial, operational, and environmental performance are found to be positive although these relationships are not statistically significant. These results are consistent with our hypotheses. GSCM is reported to have a negative impact on operational performance, which contradicts our hypothesis. However, this relationship has no statistical significance.

Reverse logistics (GI2) are positively related to financial, operational, environment and marketing performance. These results are consistent with our hypotheses. Nevertheless, only the positive relationship between reverse logistics and environmental performance is significant at $5 \%$. This finding shows evidence that the firms which recycle and reuse goods and materials to maintain product sustainability will help reduce polluted wastes and consume fewer natural resources. Our result is consistent with other findings in the research by Diabat and Govindan (2011).

Green logistics (GI3) are documented to be positively related with all firm financial, operational, environment and marketing performance. Yet, the positive relationships between financial, operational performance and green logistics are significant at $10 \%$ and 5\%, respectively. Therefore, the findings imply that green logistics help firms improve revenue, profitability, market value, firm growth and reduce costs at the same time.

Our research findings also show that both green marketing (GI4) and green advertising (GI5) have significantly positive impacts on firm performance in terms of financial, operational, environmental, and marketing performance at $1 \%$ level of significance. These results are in line with many other studies such as Fisk, 2010; Fraj et al., 2011; Green et al., 2012; and Ko et al., (2013). Building a green image of business, promoting eco-friendly products and services, and developing green marketing policies will help enhance not only firms' financial performance but also firms' operational, environmental and marketing performance as well. Our results also imply that when firms advertise their products and services that are environmentally friendly, these activities contribute to the improvement in firms' revenue, profit, market value and growth. Besides, due to the commitment of ecofriendly products, firms also reduce polluted wastes in air, water and land and reduce necessary costs to deal with environmental problems. Moreover, customers perceive environmentally friendly products of firm as great efforts, thereby, are very happy with firms' products and will be loyal to firms' products. Green business initiatives enhance firm reputation, attract new customers, improve brand awareness, customers' loyalty, sales, market growth, return on assets and investment (Agyabeng-Mensah et al., 2020).

Eco-labeling (GI6) is reported to be positively related to financial and marketing performance but negatively related to operational and environmental performance. However, the positive relationships between eco-labeling and financial and marketing performance have no statistical significance so we cannot give conclusion on these relationships. The negative relationships between eco-labeling and operational and environmental performance are significant at $5 \%$ and $1 \%$, respectively. These results contradict with findings by Tang et al., (2004) and Thogersen et al., (2010). It can be explained that eco-labeling is not popularly used by Vietnamese firms. Only the firms operating in Household \& personal product industry employ eco-labeling in their marketing strategies mostly. As a result, eco-labeling is not concisely documented by firms in other industries.

Green product innovation (GI7) has positive relationships with financial, operational, environmental, and marketing performance at $1 \%$ level of significance. Green product innovation is the mostly employed idea by Vietnamese firms among green business initiatives. The innovation may vary from the compliance of businesses with environmental regulations regarding their products production, wastes processing etc. to product innovation to reduce the negative impacts on the ecology. This result confirms that green product innovation is considered as the key to firm success nowadays because it helps firms differentiate their products and increase their market demand and market share. The firms that innovate and design green products are found to perform better than those without green initiatives (Camison and Lopez, 2012). Moreover, our findings show that when firms engage in green product innovation, they can improve financial operational performance and environmental performance. Our research results are consistent with many other studies such as Camison and Lopez (2012), Ar Ilker (2012) and Lin et al., (2013).

Table 5: Regression models results 


\begin{tabular}{|c|c|c|c|c|c|c|c|c|}
\hline & $\begin{array}{l}\text { FP } \\
\text { (Model 1.1) }\end{array}$ & $\begin{array}{l}\text { OP } \\
\text { (Model 2.1) } \\
\end{array}$ & $\begin{array}{l}\text { EP } \\
\text { (Model 3.1) }\end{array}$ & $\begin{array}{l}\text { MP } \\
\text { (Model 4.1) }\end{array}$ & $\begin{array}{l}\text { FP } \\
\text { (Model 1.2) }\end{array}$ & $\begin{array}{l}\text { OP } \\
\text { (Model 2.2) }\end{array}$ & $\begin{array}{l}\text { EP } \\
\text { (Model 3.2) }\end{array}$ & $\begin{array}{l}\text { MP } \\
\text { (Model 4.2) }\end{array}$ \\
\hline \multirow[t]{2}{*}{ GI1 } & 0.054 & -0.026 & 0.049 & 0.077 & 0.021 & -0.034 & 0.072 & $0.103 * *$ \\
\hline & $(0.064)$ & $(0.056)$ & $(0.056)$ & $(0.047)$ & $(0.062)$ & $(0.056)$ & $(0.057)$ & $(0.049)$ \\
\hline \multirow[t]{2}{*}{ GI2 } & 0.057 & 0.056 & $0.102 * *$ & 0.026 & 0.057 & 0.060 & $0.110 * *$ & 0.034 \\
\hline & $(0.050)$ & $(0.044)$ & $(0.044)$ & $(0.037)$ & $(0.049)$ & $(0.044)$ & $(0.045)$ & $(0.039)$ \\
\hline \multirow[t]{2}{*}{ GI3 } & 0.090 & $0.159 * * *$ & 0.014 & 0.062 & $0.095^{*}$ & $0.160 * * *$ & 0.013 & 0.060 \\
\hline & $(0.057)$ & $(0.050)$ & $(0.049)$ & $(0.042)$ & $(0.055)$ & $(0.049)$ & $(0.051)$ & $(0.043)$ \\
\hline \multirow[t]{2}{*}{ GI4 } & $0.251 * * *$ & $0.289 * * *$ & $0.289 * * *$ & $0.283 * * *$ & & & & \\
\hline & $(0.059)$ & $(0.052)$ & $(0.051)$ & $(0.044)$ & & & & \\
\hline \multirow[t]{2}{*}{ GI5 } & & & & & $0.331 * * *$ & $0.287 * * *$ & $0.190 * * *$ & $0.177 * * *$ \\
\hline & & & & & $(0.054)$ & $(0.048)$ & $(0.050)$ & $(0.043)$ \\
\hline \multirow[t]{2}{*}{ GI6 } & 0.109 & $-0.144 * *$ & $-0.208 * * *$ & 0.064 & 0.081 & $-0.156^{* *}$ & $-0.199 * * *$ & 0.075 \\
\hline & $(0.072)$ & $(0.063)$ & $(0.063)$ & $(0.053)$ & $(0.070)$ & $(0.063)$ & $(0.064)$ & 0.055 \\
\hline \multirow[t]{2}{*}{ GI7 } & $0.258 * * *$ & $0.246^{* * * *}$ & $0.361 * * *$ & $0.260 * * *$ & $0.221 * * *$ & $0.256 * * *$ & $0.425 * * *$ & $0.327 * * *$ \\
\hline & $(0.061)$ & $(0.054)$ & $(0.053)$ & $(0.045)$ & $(0.058)$ & $(0.052)$ & $(0.053)$ & 0.045 \\
\hline \multirow[t]{2}{*}{ Constant } & $0.457 * * *$ & $0.713 * * *$ & $1.066^{* * * *}$ & $0.855^{* * *}$ & $0.500 * * *$ & $0.750 * * *$ & $1.089 * * *$ & $0.877 * * *$ \\
\hline & $(0.142)$ & $(0.125)$ & $(0.124)$ & $(0.105)$ & $(0.138)$ & $(0.124)$ & $(0.127)$ & $(0.109)$ \\
\hline Observations & 312 & 312 & 312 & 312 & 312 & 312 & 312 & 312 \\
\hline R Squared & 0.480 & 0.489 & 0.612 & 0.643 & 0.509 & 0.495 & 0.591 & 0.615 \\
\hline
\end{tabular}

Note: $*, * *, * * *$ indicate significance level at $10 \%, 5 \%$, and $1 \%$, respectively. Standard errors are reported in the brackets.

FP is financial performance and is reflected by FP1-3; OP is operational performance and is reflected by OP1-3; EP is environmental performance and is reflected by EP1-2; MP is marketing performance and is reflected by MP1-3; GI1 measure GSCM; GI2 is reverse logistics; GI3 is green logistics; GI4 is green marketing; GI5 is green advertising; GI6 is eco-labeling; GI7 is green product innovation.

Table 6 reports the overall impact of green business initiatives (GI) on firm performance (FP, OP, EP and MP). Green business initiatives are measured by individual initiative such as GSCM, reverse logistics, green logistics, green marketing, green advertising, eco-labeling, and green product innovation. Our research finds that green business initiatives have statistically significant positive impacts on Vietnamese firms' financial performance, operational, environmental, and financial performance. This result once again confirms the significant role of green initiatives in firm performance. Green initiatives not only help firms enhance environmental performance, but also improve financial, operational, and marketing performance. Our hypothesis is therefore accepted, and our results are also in line with many previous studies in the field (e.g. Simpson et al., 2007; Leonidou et al., 2012; Brecard, 2011; Kushwaha and Sharma, 2016).

The R-squared values in our models range from 0.48 to 0.62 , indicating that our models help explain $48 \%$ - $62 \%$ the relationships between green business initiatives and firm performance, which is satisfactory. The Durbin-Watson values show that there is no superlative chain correlation in the model

Table 6: Regression results for green business initiatives and firm performance

\begin{tabular}{|l|l|l|l|l|}
\hline & $\begin{array}{l}\text { FP } \\
\text { (Model 5.1) }\end{array}$ & $\begin{array}{l}\text { OP } \\
\text { (Model 5.2) }\end{array}$ & $\begin{array}{l}\text { EP } \\
\text { (Model 5.3) }\end{array}$ & $\begin{array}{l}\text { MP } \\
\text { (Model 5.4) }\end{array}$ \\
\hline GI & $0.696^{* * *}$ & $0.665^{* * *}$ & $0.724 * * *$ & $0.777^{* * *}$ \\
\hline & $(0.054)$ & $(0.049)$ & $(0.052)$ & $(0.042)$ \\
\hline (Constant) & $0.434^{* * *}$ & $0.680^{* * *}$ & $0.823^{* * *}$ & $0.831^{* * *}$ \\
\hline & $(0.126)$ & $(0.116)$ & $(0.122)$ & $(0.098)$ \\
\hline R Squared & 0.485 & 0.442 & 0.525 & 0.604 \\
\hline Durbin-Watson & 1.709 & 1.750 & 1.591 & 1.799 \\
\hline
\end{tabular}

Note: $*, * * * *$ indicate significance level at $10 \%, 5 \%$, and $1 \%$, respectively. Standard errors are reported in the brackets.

GI1 measure GSCM; GI2 is reverse logistics; GI3 is green logistics; GI4 is green marketing; GI5 is green advertising; GI6 is eco-labeling; GI7 is green product innovation. FP is financial performance; OP is operational performance; EP is environmental performance; MP is marketing performance.

\section{Conclusion}

Environmental issues have become a major concern for businesses. Firms are facing increasing pressures from environmental regulations and have been investing on R\&D to develop products that can reduce damage to the ecology (McKinsey, 2013).
Controlling carbon emissions is the biggest challenge for automobile industry (Kushwaha and Sharma, 2016). As a result, green business initiatives have been considered as innovative solutions to help firms minimize the negative impacts on the 
environment and achieve sustainable development. However, some managers find green business initiatives unpersuasive as their concerns are related to the costs and benefits of green business initiatives. Our research aims at examining how Vietnamese firms employ green business initiatives and whether these initiatives have any impacts on firm performance. Our findings show evidence that the adoption of green initiatives such as GSCM, reverse logistics, green logistics, green marketing, green advertising, eco-labeling and green product innovation, partly or as a whole, contribute to the enhancement of firms' financial performance, operational performance, environmental and marketing performance. GSCM (GI1) is found to have a positive relationship with marketing performance while reverse logistics (GI2) are positively related to environment performance. Green logistics (GI3) are documented to be positively related with all firm financial and operational performance. Our research findings also show that both green marketing (GI4) and green advertising (GI5) have significantly positive impacts on firm performance in terms of financial, operational, environmental, and marketing. Nevertheless, we document negative relationships between eco-labeling and operational and environmental performance. We also find that ecolabeling is least applied by Vietnamese firms among the green business initiatives. In contrast, green product innovation (GI7) is mostly employed by Vietnamese firms and is documented to have positive relationships with all financial, operational, environmental, and marketing performance. Overall, our findings confirm that there is a significant positive relationship between green business initiatives and firm performance. We suggest that firms should adopt green business initiative to reduce harmful impacts on the natural environment and to achieve sustainable growth, thereby, creating a solid foundation for the development of green economy.

Our study has some limitations. Our sample size is relatively small. Besides, the adoption of some green initiatives might be adopted by a small number of firms in some industries, therefore, we might not be able to fully capture the impacts of certain green business initiatives on firm performance. Future studies can extend the sample size and ensure that the number of firms in different industries are evenly included in the sample. Besides, future studies can conduct PLS-SEM or other suitable techniques to explore and analyse the impact of green business initiatives on firm performance.

\section{Data Availability}

If you are interested in the data used in this research, you can contact us through our email.

\section{Funding Statement}

This study is part of the granted project by Vietnam Ministry of Education and Training coded B2018 - NTH - 20.

\section{Conflicts of Interest}

"The author(s) declare(s) that there is no conflict of interest regarding the publication of this paper."

\section{References:}

[1] Agyabeng-Mensah Y., Afum E., and Ahenhorah E. (2020), "Exploring financial performance and green logistics management practices: Examining the mediating influences of market, environmental and social performances", Journal of cleaner production 258, p120616.

[2] Ar Ilker, M. (2012), "The impact of green product innovation on firm performance and competitive capability: the moderating role of managerial environmental concern", Procedia Social and Behavioral Sciences, Vol. 62, pp. 854-864.

[3] Azevedo, S., Carwalho, H., Machado, V. (2011), “The influence of green initiatives on supply chain performance: a case study approach", Transportation Research Part E: Logistics and Transportation Review, Vol. 47, pp. 850-871.

[4] Baah, C., Jin, Z., Tang, L. (2019), “Organizational and regulatory stakeholder pressures friends or foes to green logistics practices and financial performance: investigating corporate reputation as a missing link", Journal of cleaner production 247, pp 119-125.

[5] Beise-Zee, R. \& Rennings, K. (2005), "Lead markets and regulation: A framework for analyzing the international diffusion of environmental innovations. Ecological Economics 52, pp 5-17.

[6] Brecard, D. (2011), "Environmental tax in a green market", Environmental Resource Economics 49, 387 403.

[7] Borin, N., Cerf, C. (2011), "Consumer effects of environmental impact on product labeling”, Journal of Consumer Marketing 28 (1), pp 76-86.

[8] Bose, L., Pal, R. (2012), "Do green supply chain management impact stock prices of the firm", Decision Support System, Vol. 52, pp. 624-634.

[9] Bowen, F.E., Cousins, P.D., Lamming, R.C., Faruk, A.C. (2001), "The role of supply management capabilities in green supply", Journal of Production and Operation Management Society Vol. 10 No. 2, pp. 174-189.

[10] Camino, J.R. (2007), "Re-evaluating green marketing strategy: a stakeholder perception", European Journal of Marketing, Vol. 41 No. 11-12, pp. 1328-1358.

[11] Camison, C., Lopez, A. (2012), "Organization innovation as an enabler of technology, innovation capabilities and firm performance", Journal of Business Research 67 (1), pp 2891-2902.

[12] Caniels, M. (2013), "Participation of suppliers in the greening supply chain: an empirical analysis of German automotive suppliers", Journal of Purchasing and Supply Management, Vol. 19, pp. 134-143.

[13] Centobelli, P., Cerchione, R., Esposito, E. (2018), "Environmental sustainability and energy-efficient supply chain management: a review of research trends and proposed guidelines", Energies 11 (2), pp275.

[14] Chan, R.Y., He, H., Chan, H.K., Wang, W.Y. (2012a), "Environment orientation and corporate performance: the mediation mechanism of green supply chain management and the moderating effect of competitive intensity", Industrial Marketing Management, Vol. 41 No. 4, pp. 621-630.

[15] Chan, H.K., He, H., Wang, W. (2012b), "Green marketing and its impact on supply chain in industrial markets", Industrial Marketing Management 41, 557562.

[16] Chen, Y.S., Lin, C.L., Chang, C.H. (2013), “The influence of green wash on green wordof-mouth(green WOM): the mediation effects of green perceived quality 
and green satisfaction”, Quality \& Quantity: International Journal of Methodology, Vol. 48 No. 5, pp. 2411-2425.

[17] Cronin Jr., J.J., Smith, J.S., Gleim, M.R., Ramirez, E., Martinez, J.D. (2011) "Green marketing strategies: an examination of stakeholders and the opportunities they present", Journal of Academy of Marketing Science 39 (1), pp 158-174.

[18] Demirel, E., Demirel, N., G€okçen, H. (2016), “A mixed integer linear programming model to optimize reverse logistics activities of end-of-life vehicles in Turkey", Journal of Cleaner Production 112, 2101-2113.

[19] Dheeraj, N., Vishal, N. (2012), "An overview of green supply chain management in India”, Research Journal of Recent Sciences, Vol. 1 No. 6, pp. 77-82.

[20] Diabat, A., Govindan, K. (2011), "An analysis of the drivers affecting the implementation of green supply chain management", Resources Conservation \& Recycling, Vol. 55 No. 6, pp. 659-667.

[21] Dias, K., T., Braga Junior, S., S. (2016) "The use of reverse logistics for waste management in a Brazilian grocery retailer", Waste Management Resources, 34 (1), pp 22-29.

[22] Fisk, G. (2010) "Green marketing: a multiplier for appropriate technology transfer", Journal of Marketing Management, Vol. 17 No. 6, pp. 657-676.

[23] Fraj, E., Martinez, E., Matute, J. (2011), "Green marketing strategy and the firm's performance: the moderating role of environmental culture", Journal of Strategic Marketing, Vol. 19 No. 4, pp. 339-355.

[24] Gleim, M.R. (2013), “Against the green: a multimethod examination of the barriers to green consumption", Journal of Retailing, Vol. 44, pp. 44-6.

[25] Green Jr., K.W., Whitten, D., Inman, R.A. (2012), "Aligning marketing strategies throughout the supply chain to enhance performance", Indudustrial Marketing Management, Vol. 41, pp. 1008-1018.

[26] Grimmer, M., Wooley, M. (2014) “Green marketing messages and consumers' purchase intention: promoting personal versus environmental benefits", Journal of Marketing Communication 20 (4), 231-250.

[27] Hansmann, K.W., Claudia, K. (2001), "Environmental management policies", In: Sarkis, J. (Ed.), Green Manufacturing and Operation: From Design to Delivery and Back, Sheffield, UK: Greenleaf Publishing.

[28] Hazen, B.T., Wu, Y., Cegielski, C.G., Jones-Farmer, L.A., Hall, D.J. (2012), "Consumer reaction to the adoption of green reverse logistics, the international review of retail", The International Review of Retail Distribution and Consumer Research, Vol. 22 No. 4, pp. 417 - 434.

[29] Hervani, A., Helms, M., Sarkis, J. (2005), "Performance measurement for green supply chain management", Benchmark International Journal, Vol. 12 No. 4, pp. 330353.

[30] Juwaheer, T.D., Pudaruth, S., Noyaux, M.E. (2012), "Analyzing the impact of green marketing strategies on consumer purchasing patterns in Mauritius", World Journal of Entrepreneurship Management Sustainable Development, Vol. 8 No. 1, pp. 36-59.

[31] Kasilingam, L., Selvam, M., Vinayagamoorthi, V. (2014), "The Stock Market Efficiency of Emerging
Markets: Evidence from Asian Region". Asian Social Science, Vol. 10, pp. 158-168.

[32] Khan, S.A.R., Jian, C., Yu, Z., Golpîra, H., Kumar, A. (2019), "Impact of green practices on Pakistani manufacturing firm performance: a path analysis using structural equation modeling", In: Computational Intelligence and Sustainable Systems. Springer, Cham, pp 87-97.

[33] Ko, E., Hwang, Y.K., Kim, E.Y. (2013), “Green marketing functions in building a corporate image in the retail setting”, Journal of Business Resources, Vol. 66 No. 10, pp. 1709 - 1715.

[34] Kock, N. (2015), "Common method bias in PLS-SEM: a full collinearity assessment approach", International Journal of e-Collaboration 11 (4), pp 1-10.

[35] KPMG International, (2014), "Global Automotive Executive Survey".

[36] Kristrom, B., Lundgreen, T. (2003) "Abatement investments and green goodwill”, Applied Economics 35 (18), pp 1915-1921.

[37] Kurdve, M., Zackrisson, M., Wiktorsson, M., Harlin, U. (2014), "Lean and green integration into production system models - experiences from Swedish industry", Journal of Cleaner Production, Vol. 85, pp. 180 - 190.

[38] Kushwaha G., S., and Sharma N., K. (2016), "Green initiatives: a step towards sustainable development and firm's performance in the automobile industry", Journal of cleaner production, 121, pp 116-129.

[39] Leonidou, C.N., Katsikeas, C., S., Morgan, N., A. (2012) "Greening the marketing mix: do firms do it and do it pay off?", Journal of the Academy of Marketing Science 41 (2), p151-170.

[40] Lin, R.J., Tan, K.H., Geng, Y. (2013), "Market demand, green product innovation, and firm performance: evidence from Vietnam motorcycle industry", Journal of Cleaner Production, Vol. 40, pp. 101-107.

[41] Luthra, S, Kumar, V., Kumar, S., Haleem, A. (2011), "Barriers to implementing green supply chain management in automobile industry using interpretive structured modeling techniques: an Indian perspective", Journal of Industrial and Engineering and Management, Vol. 4 No. 2, pp. 231-257.

[42] Mathiyazhagan, K., Govindan, K., NoorulHaq, A., Geng, Y. (2013), "An ISM approach for the barrier analysis in implementing green supply chain management", Journal of Cleaner Production, Vol. 47, pp. 283-297.

[43] McKinsey and Company (2013), "The road to 2020 and beyond: what's driving the global automotive industry", available

https://www.mckinsey.com/industries/automotive-andassembly/our-insights/the-road-to-2020-and-beyondwhats-driving-the-global-automotive-industry (accessed December 26, 2019).

[44] Panda, L.K., Goswami, S. (2009), "Eco-labels and its environmental countenance", Orissa Review, October 2009, available at http://magazines.odisha.gov.in/Orissareview/2009/Octob er/engpdf/Pages64-71.pdf, (accessed December 26, 2019).

[45] OECD (2009), "Sustainable manufacturing and ecoinnovation: towards a green economy", available at https://www.oecd.org/env/consumptioninnovation/42957785.pdf (accessed December 26, 2019). 
[46] Peattie, K., Crane, A. (2005), "Green marketing: legend, myth, farce, prophesy?", Qualitative Marketing Research, Vol. 8 No. 4, pp. 357-370.

[47] Polonsky, M.J., Rosenberger, P.J. (2001), "Reevaluating green marketing: a strategic approach", Business Horizon, Vol. 44 No. 5, pp. 21-30.

[48] Rao, P. (2002), "Greening the supply chain: a new initiative in South East Asia", International Journal of Operation and Production Management, Vol. 22 No. 6, pp. 632-655.

[49] Rao, P., and Holt, D. (2005), "Do green supply chains lead to competitiveness and economic performance?", International Journal of Operation \& Production Management, Vol. 25 No. 9, pp. 898 - 916.

[50] Reid, A. and Miedzinski, M. (2008), "Eco-innovation", Final Report for Sectoral Innovation Watch, Brussels, Technopolis Group, DOI:10.13140/RG.2.1.1748.0089.

[51] Rex, E., Baumann, H. (2007), "Beyond eco-labels: what green marketing can learn from conventional marketing”, Journal of Cleaner Produciton, pp. 567-576.

[52] Rodrigue, J-P. and Slack, B. and Comtois, C. (2001), "Green Logistics (The Paradoxes of)". The Handbook of Logistics and Supply-Chain Management.

[53] Samad, S. (2012), "The influence of innovation \& transformational leadership on organization performance", Procedia Social and Behavioral Sciences, Vol. 57, pp. 486 - 493.

[54] Saxena, R.P., Khandelwal, P.K. (2008), "Consumer attitudes towards green marketing on an exploratory study", The International Journal of Indian Psychology, Vol. 2, pp. 140 - 146.

[55] Saxena, R.P., Khandelwal, P.K. (2012), "Greening of industries for sustainable growth, an exploratory study on durable, non-durable \& services industries", International Journal Social Economics, Vol. 39 No. 8, pp. 551-586.

[56] Sbihi, A., Eglese, R.W. (2010), "Combinatorial optimization and Green Logistics", Annals of Operations Reserarch 175, pp 159-175.

[57] Sharma, A., Iyer, G.R. (2012), "Resource-constrained product development, the implication for greenmarketing and green supply chains", Industrial Marketing Management, Vol. 41, pp. 599-608.

[58] Shen, L., Olfat, L., Govindan, K., Khodaverdi, R., Diabat, A. (2013), “A fuzzy multi criteria approach for evaluating green supplier's performance in green supply chain with linguistic preferences", Resources, Conservation and Recycle, Vol. 74, pp. 170-179.

[59] Simpson, D., Power, D., Samson, D. (2007), "Greening the automotive supply chain: a relationship perspective", International Journal of Operational Production Management. 27 (1), 28-48.

[60] Siriwardena, S., Hunt, G., Teisl, M.F., Noblet, C.L. (2012), "Effective environmental marketing of green cars: a nested logit approach". Transportation Research Part D, pp 237-242.

[61] Smith, K.T. (2012), "A longitudinal study of green marketing strategies that influence millennial", Journal of Strategic Marketing, Vol. 20 No. 6, pp. 535-551.

[62] Tang, E., Fryxell, G.E., Chow, C.F. (2004), "Visual \& verbal communication in the design of eco-labels for green consumer products", Journal of International Consumer Marketing, Vol. 16 No. 4, pp. 85- 105.

[63] Tseng, M.L., Tan, K., Lim, M., Lin, R.J., Geng, Y. (2014b), "Benchmarking eco-efficiency in green supply chain practices in uncertainty", Production Planning and Control, Vol. 25 No. 13 - 14, pp. 1079 - 1090.

[64] Tseng, M.L., Tan, K., Chiu, A.S.F. (2015), "Identifying the competitive determinants of firms' green supply chain capabilities under uncertainty", Clean Technologies Environmental Policy, Vol. 18, pp. 12471262.

[65] Thogersen, J., Haugaard, P., Olesen, A. (2010), "Consumer responses to eco-labels", European Journal of Marketing. Vol. 44 No. 11-12, pp. 1787-1810.

[66] Zhu, Q., Sarkis, J. (2004), "Relationships between operational practices and performance among early adopters of green supply chain management practices in Chinese manufacturing enterprises", Journal of Operations Management, Vol. 22 No. 3, pp. 265 - 289. 